\title{
When should we discontinue antiarrhythmic therapy for atrial fibrillation after abdominal surgery?
}

\author{
Gennaro Pagano ${ }^{1 *}$, Dario Leosco ${ }^{1}$, Nicola Ferrara ${ }^{1,2}$, Nicola Rocco $^{3}$, Corrado Rispoli $^{4}$, Loredana lannone ${ }^{5}$, \\ Serena Testa ${ }^{4}$, Rita Compagna ${ }^{6}$, Antonello Accurso ${ }^{6}$, Bruno Amato ${ }^{6}$
}

From 26th National Congress of the Italian Society of Geriatric Surgery

Naples, Italy. 19-22 June 2013

\section{Aim of the study}

The purpose of this study was to determine whether the duration of antiarrhythmic therapy after discharge from the hospital following abdominal surgery is related to the incidence of atrial fibrillation (AF) recurrence in elderly patients with the occurrence of peri-operative AF.

\section{Background}

The occurrence of peri-operative AF after abdominal surgery is a clinical condition burdened by several complications, especially in the elderly [1-3]. When AF is successfully converted to sinus rhythm, it is unlikely to recur, and nearly all of these patients are discharged from the hospital in sinus rhythm. It is not clear how soon these patients may discontinue antiarrhythmic therapy to avoid drugs side effects without risking recurrence of AF.

The recurrence of AF needs different kind of treatment. Medical therapy includes various antiarrhythmic drugs to control heart rate and restore sinus rhythm and anticoagulation to reduce the tromboembolic risk [4]. Overactivation of sympathetic nervous system, related to surgery stress [5], could be reduced by the treatment with antiarrhythmic drugs, such as Beta Blockers, and may reduce the incidence of AF recurrence [6-10].

\section{Methods}

A pilot study was conducted in 19 elderly patients (age $>65$ years) who underwent abdominal surgery (right emicolectomy, sigmoidectomy and anterior rectal resection) and with occurrence of peri-operative AF that

\footnotetext{
* Correspondence: gennaropagano85@hotmail.com

'Department of Translational Medical Sciences, Federico II University of Naples, Naples, Italy

Full list of author information is available at the end of the article
}

successfully reverted to sinus rhythm. They were prospectively randomized at dismissal to receive antiarrhythmic therapy for 1 week (six patients in group A), 3 weeks (seven patients in group B), or 6 weeks (six patients in group C). Patients were followed up for an additional 4 weeks after discontinuation of antiarrhythmic therapy for detection of recurrence of AF.

\section{Results}

There was no significant difference in the recurrence of $\mathrm{AF}$ among groups $(0 \%, 2 \%$, and $0 \%$ for groups $\mathrm{A}, \mathrm{B}$, and $C$, respectively).

\section{Conclusions}

In elderly patients with peri-operative AF after abdominal surgery, converted to normal sinus rhythm before hospital discharge, have a benign course and the duration of antiarrhythmic therapy shorter than one week is appropriate.

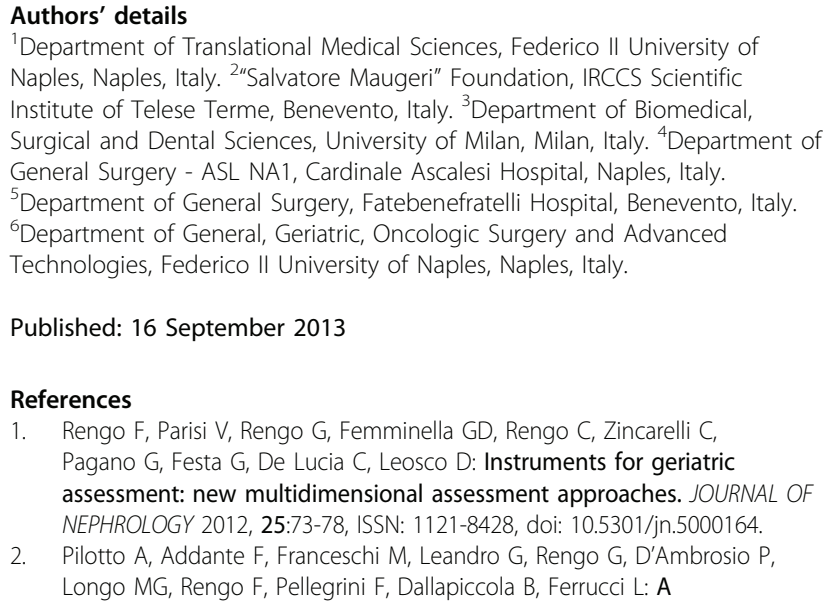

Published: 16 September 2013 assessment: new multidimensional assessment approaches. JOURNAL OF NEPHROLOGY 2012, 25:73-78, ISSN: 1121-8428, doi: 10.5301/jn.5000164.

2. Pilotto A, Addante F, Franceschi M, Leandro G, Rengo G, D'Ambrosio P, Longo MG, Rengo F, Pellegrini F, Dallapiccola B, Ferrucci L: A 
Multidimensional Prognostic Index (MPI) based on a Comprehensive Geriatric Assessment Predicts Short-Term Mortality in Older Patients with Heart Failure. Circulation: Heart Failiure 2010, 3:14-20.

3. Rispoli C, Rocco N, lannone L, Amato B: Developing guidelines in geriatric surgery: role of the grade system. BMC Geriatrics 2009, 9(SUPPL.1):A99.

4. Rengo G, Pagano G, Squizzato A, Moja L, Femminella GD, de Lucia C, Komici K, Parisi V, Savarese G, Ferrara N, Perrone-Filardi P, Leosco D: Oral anticoagulation therapy in heart failure patients in sinus rhythm: a systematic review and meta-analysis. PloS One 2013, 8(1):e52952, doi:10.1371/journal.pone.0052952.

5. Paolillo S, Rengo G, Pagano G, Pellegrino T, Savarese G, Femminella GD, Tuccillo, Boemio A, Attena E, Formisano R, Petraglia L, Scopacasa F, Galasso G, Leosco D, Trimarco B, Cuocolo A, Perrone-Filardi P: Impact of Diabetes Mellitus on Cardiac Sympathetic Innervation in Patients With Heart Failure. A lodine-123 meta-iodobenzylguanidine (1123MIBG) Scintigraphic Study. Diabetes Care 2013.

6. Rengo G, Lymperopoulos A, Zincarelli C, Femminella Gd, Liccardo D, Pagano G, de Lucia C, Cannavo A, Gargiulo P, Ferrara N, Perrone Filardi P, Koch Wj, Leosco D: Blockade of beta-adrenoceptors restores the GRK2mediated adrenal alpha(2) -adrenoceptor-catecholamine production axis in heart failure. BRITISH JOURNAL OF PHARMACOLOGY 2012, 166:2430-2440, ISSN: 1476-5381, doi: 10.1111/j.1476-5381.2012.01972.x.

7. Rengo G, Zincarelli C, Femminella GD, Liccardo D, Pagano G, de Lucia C, Altobelli GG, Cimini V, Ruggiero D, Perrone-Filardi P, Gao E, Ferrara N, Lymperopoulos A, Koch WJ, Leosco D: Myocardial beta(2) -adrenoceptor gene delivery promotes coordinated cardiac adaptive remodelling and angiogenesis in heart failure. BRITISH JOURNAL OF PHARMACOLOGY 2012, 166:2348-2361, ISSN: 1476-5381, doi: 10.1111/j.1476-5381.2012.01954.x.

8. Rengo G, Perrone-Filardi P, Femminella GD, Liccardo D, Zincarelli C, de Lucia C, Pagano G, Marsico F, Lymperopoulos A, Leosco D: Targeting the beta-adrenergic receptor system through $\mathrm{G}$-protein-coupled receptor kinase 2: a new paradigm for therapy and prognostic evaluation in heart failure: from bench to bedside. CIRCULATION. HEART FAILURE 2012, 5:385-391, ISSN: 1941-3289, doi: 10.1161/CIRCHEARTFAILURE.112.966895.

9. Rengo G, Leosco D, Zincarelli C, Marchese M, Corbi G, Liccardo D, Filippelli A, Ferrara N, Lisanti MP, Koch WJ, Lymperopoulos A: Adrenal GRK2 lowering is an underlying mechanism for the beneficial sympathetic effects of exercise training in heart failure. American Journal of Physiology - Heart and Circulatory Physiology 2010, 24(9).

10. Leosco D, Rengo G, laccarino G, Golino L, Marchese M, Fortunato F Zincarelli C, Sanzari E, Ciccarelli M, Galasso G, Altobelli GG, Conti V, Matrone G, Cimini V, Ferrara N, Filippelli A, Koch WJ, Rengo F: Exercise promotes angiogenesis and improves $\beta$-adrenergic receptor signalling in the post-ischaemic failing rat heart. Cardiovascular Research 2008, 30(3).

doi:10.1186/1471-2482-13-S1-A35

Cite this article as: Pagano et al:: When should we discontinue antiarrhythmic therapy for atrial fibrillation after abdominal surgery? BMC Surgery 2013 13(Suppl 1):A35.

\section{Submit your next manuscript to BioMed Central and take full advantage of:}

- Convenient online submission

- Thorough peer review

- No space constraints or color figure charges

- Immediate publication on acceptance

- Inclusion in PubMed, CAS, Scopus and Google Scholar

- Research which is freely available for redistribution

Submit your manuscript at www.biomedcentral.com/submit 